\title{
SOCIAL EMPOWERMENT TO ACHIEVE FOOD SECURITY AT THE BORDERS: A CASE STUDY AT NORTH SEBATIK SUBDISTRICT OF NUNUKAN REGENCY (NORTH KALIMANTAN PROVINCE, INDONESIA)
}

\author{
Suryana Nia Kurniasih*, Pudjiwati Eko Hary \\ University of Borneo Tarakan, Indonesia \\ *E-mail : zlynia@gmail.com
}

\begin{abstract}
Food security plays strategic role in national development. Food security does not only mean adequate food availability, but also ability to access (including purchase) foods and does not refer to food-dependent upon anyone. Excessive food availability, which is not accompanied with sufficient access to foods and optimal absorption of foods, will create food scarcity. The area of North Sebatik Subdistrict is divided into two parts, however, a part belongs to Indonesia area and the other one belongs to Malaysia. This island is one of outer islands, which should become the main priority of development due to it borders on the neighboring country. Foods become very crucial problem due to they do not only affect on human resources quality, but also on national defense. Social empowerment could be encouraged by improving human resources capacity in order to create and raise income of the household through farming activity. Objectives of the research were to analyze the empowerment level and to analyze food security level at North Sebatik Subdistrict. The research used both qualitative and quantitative approaches in order to catch the essence of facts and social problems accurately. Results of the research showed that social empowerment (farmers) level at North Sebatik has scored 2 on average and considered as moderate criteria. Moreover, food security of the society (farmers) at North Sebatik also has scored 2 on average and considered as moderate criteria.
\end{abstract}

\section{KEY WORDS}

Social empowerment, food security, food, borderline.

Food security does not only mean adequate food availability, but also ability to access (including purchase) foods and does not refer to food-dependent upon anyone. Excessive food availability, which is not accompanied with sufficient access to foods and optimal absorption of foods, will create food scarcity (Mun'im, 2012). Husodo (2002) suggested comparison between food production volume and numbers of population, which does not mean that none may experience lack of foods, however, foods problem has nothing to do with production availability, but it relates to distribution and access to foods.

The area of North Sebatik Subdistrict is divided into two parts, however, a part belongs to Indonesia area and the other one belongs to Malaysia. This island is one of outer islands, which should become the main priority of development due to it borders on the neighboring country. Sebatik Island has much potency of diverse sectors, such as agriculture, plantation, fishery, and tourism.

Empirical facts showed that almost the whole main necessities of the people at Sebatik Island depend on supplies from Malaysia, and of course, it may threat food security and national defense. In accordance with the Government's Regulation Number 68 in 2002 about Food Security, efforts to realize the national food security should be based on local food resources that have high variability among regions and should avoid any dependence of imported-foodstuff. In order to bring the food security into reality, all sectors should play their roles actively and well coordinate with Central Government, Provincial Government, Municipal Government, Local Government at Village level, and society to improve and realize the national defense. Objectives of the research were to analyze social empowerment (farmers) in order to achieve food security at the North Sebatik Subdistrict and to analyze food security level of the society (farmer) at the North Sebatik Subdistrict. 


\section{LITERATURE REVIEW}

Social Empowerment. Empowerment refers to ability to participate in taking opportunity and, or to access the required resources and services in order to improve quality of their lives. Society is the actor in relation to their ideas as basis for local, regional, and national development programs (Mardikanto, 2010). In development, social empowerment is very crucial due to it protects social interest (Galié, 2013).

Social empowerment means developing social ability to be self-supported and have skills to overcome their own problems by strengthening social ability to get involved in each process of development dynamically (Sugiyanto, 2010) and becomes a tough device for problem-solving (Kasmel, 2011).

Wrihatnolo and Dwidjowijoto (2007) suggested that the process of empowerment has three stages as follow:

Awareness refers to "enlightenment" given to the potential target by awakening them that they have right to have something;

Capacity building refers to the targets should have ability first before they are given authority or power;

Empowerment refers to the targets that have been given power, authority, or opportunity in accordance with quality of their skills.

Empowerment as a theoretical form could be traced from a humanitarian and educator, Freire, who stated that a plan to free the suppressed people in this world is through education (Hur, 2006). Empowerment may be applied by increasing access to resources, improving social ability, and strengthening the institution (Westendorp, 2013). Langerodi (2013) suggested that factors, which affect empowerment, are age, capital, training, and problem-solving. Meanwhile, Babu (2013) stated that the empowerment components include knowledge, decision-making, and self-confidence.

In general, indicators of social empowerment include welfare, access, and participation, bravery to take risk, awareness and decision-making. Indicators of empowerment level as direct and indirect consequences of social empowerment program, based on results of research by Firmansyah (2012) suggested four parameters of social empowerment levels, such as (1) awareness and willingness to change (power within); (2) ability to increase capacity to get access (power to); (3) ability to overcome obstacles (power over); ability to establish cooperation and solidarity (power with).

Food Security. Laws on Foods No 18 in 2012 define food security as condition of food fulfillment for the country and personal, which reflected from sufficient food availability, both quantity and quality, safe, variety, nutritious, evenly, and achievable, as well as not incompatible with religion, faith, and socio-culture to live healthy, actively, and productive continually.

Objectives of food security must be oriented to achieve right fulfillment for foods, increase quality of human resources, and national food security. The operation of such food security system highly depends on policy and performance of the economic, social, and political sectors. The government's policies in economic, social, and political aspects affect on food security. Food security development must be viewed as a part of national defense concept. Therefore, the government should push the food security development through programs, which really could strengthen food security and increase social welfare (Kompasiana, 2013).

Basically, national food policies comprise of: (1) efficient growth in foods and agricultural sectors; (2) improving income distribution, particularly in creating efficient work opportunity; (3) nutrient status that conform to the whole populations by fulfilling their basic necessities; (4) sufficient food security to face any fluctuation of production, prices, income, and possibility of unavailable foods supply (Darmawan, 2011). Food security levels may be measured using some indicators. Indicator of food security in regional level is different from indicator of food security in household level. Mun'im (2012) suggested the differences as follow: 
Table 1 - Different Indicators of Regional Foods Security and Food Security in the Household

\begin{tabular}{|c|c|c|}
\hline \multirow{2}{*}{$\begin{array}{c}\text { Variable of Food } \\
\text { Security }\end{array}$} & \multicolumn{2}{|c|}{ Indicator } \\
\hline & Regional & Household \\
\hline $\begin{array}{l}\text { Food } \\
\text { availability }\end{array}$ & $\begin{array}{l}\text { Normative consumption ratio } \\
\text { Average consumption of calorie per } \\
\text { capita per day } \\
\text { Average consumption of protein per } \\
\text { capita per day }\end{array}$ & $\begin{array}{l}\text { Produce the food by themselves } \\
\text { Purchase the foods } \\
\text { Food aid } \\
\text { Food reserves }\end{array}$ \\
\hline $\begin{array}{c}\text { Food } \\
\text { accessibility }\end{array}$ & $\begin{array}{l}\text { Percentage of not poor people } \\
\text { Percentage of average expenses of the } \\
\text { households for non-foods consumption } \\
\text { Percentage of villages, which are } \\
\text { passed through by } 4 \text {-wheels vehicles } \\
\text { Percentage of villages for market } \\
\text { access }\end{array}$ & $\begin{array}{l}\text { Income of the head of family } \\
\text { Income of the wife } \\
\text { Income of the family's members } \\
\text { Allocation of income for foods } \\
\text { Allocation of income for non-foods }\end{array}$ \\
\hline $\begin{array}{c}\text { Food } \\
\text { absorption }\end{array}$ & $\begin{array}{l}\text { Percentage of households, which } \\
\text { consume water } \\
\text { Percentage in using toilet } \\
\text { Percentage for head of family who } \\
\text { graduates from Junior High School } \\
\text { Percentage of households that have } \\
\text { access to health service facilities }\end{array}$ & $\begin{array}{l}\text { Adequacy of energy } \\
\text { Adequacy of protein } \\
\text { Adequacy of vitamin } \\
\text { Foods diversity }\end{array}$ \\
\hline
\end{tabular}

Sources: Mun'im (2012).

\section{METHODS OF RESEARCH}

Based on objectives of the research, mixed methods were used by combining both quantitative and qualitative approaches. The research was conducted at North Sebatik Subdistrict of Nunukan Regency. Sebatik Subdistrict locates at the East end of Nunukan Regency and it lies at Sebatik Island, which is divided into two areas, a part belongs to Indonesia, and the other part belongs to Sabah, Malaysia. Data of the research comprises of primary and secondary data. Data of the research was collected through some methods, such as: observation in the field, interview, questionnaire distribution and deep interview. Populations of the research were members of the farmer groups, 195 farmers, at the North Sebatik Subdistrict. Samples were taken using Simple Random Sampling technique with 65 farmers as the sample. Data analysis used scoring.

Table 1 - Indicator and Parameter of the Research

\begin{tabular}{lll}
\hline No & \multicolumn{1}{c}{ Indicator } & \multicolumn{1}{c}{ Parameter } \\
\hline \multirow{3}{*}{ Social empowerment } & Awareness and willingness to change (power within) \\
& Ability to increase capacity to get access (power within) \\
& Ability to overcome obstacles (power over) \\
& Ability to establish cooperation and solidarity (power with) \\
\hline \multirow{3}{*}{2} & Food security & Food availability \\
& & Food accessibility \\
& Food absorption
\end{tabular}

\section{RESULTS AND DISCUSSION}

Social Empowerment Level. General objective of such empowerment programs was increasing social empowerment and self-support by improving productivity of farming operation in order to increase income and social welfare. Based on results of the research, social empowerment level of the farmers on food security at the North Sebatik Subdistrict is considered moderate. Moreover, average scores of the farmer's empowerment are presented in Table 2.

Based on Table 2 above, indicators of social empowerment in food security can be viewed from awareness and willingness to change behaviors in order to fulfill the needs for foods, ability to increase capacity to get access by increasing income, ability to face and overcome any obstacle in order to fulfill the needs for foods, as well as ability to cooperate. 
Results of the research showed that average scores for awareness and willingness to change are 3, which are categorized high. Low farmers' empowerment in management farming aspect is determined by quality of program implementation, weak role of the assistant, low environmental support and access, as well as improper learning process of the farmers and characteristics of the farmers (Aminah et al. 2015). Meanwhile, Laily (2014) suggested that factors, which affect farmers' empowerment in increasing food security, include quality of human resources, lack of farming machineries and governmental assistances.

Table 2 - Average Scores of the Farmer's Empowerment on Food Security at North Sebatik Subdistrict

\begin{tabular}{llcccccc}
\hline \multirow{2}{*}{ No } & \multirow{2}{*}{ Description } & \multicolumn{2}{c}{ Frequency (people) } & \multirow{2}{*}{ Average Score } & \multirow{2}{*}{ Criteria } \\
\cline { 3 - 6 } & & High & Moderate & Low & & High \\
\hline 1 & Awareness and willingness to change & 53 & 12 & - & 3 & Moderate \\
\hline 2 & Ability to increase capacity to get access & 35 & 30 & - & 2 & Moderate \\
\hline 3 & Ability to overcome obstacles & - & 65 & - & 2 & High \\
\hline 4 & Ability to cooperate & & & & & 3 & Moderate \\
\hline
\end{tabular}

Source: Primary Data Processing, 2017.

Food Security Level. Food security level refers to ability of the household to fulfill the needs for foods whether from foods availability, food accessibility, and food absorption aspects. Based on results of the research, food security at the North Sebatik Subdistrict was categorized moderate on average. Scores and criteria for each aspect of food security are presented in Table 3 below.

Table 3 - Average Scores of Food Security at the North Sebatik Subdistrict

\begin{tabular}{|c|c|c|c|c|c|c|}
\hline \multirow{2}{*}{ No } & \multirow{2}{*}{ Description } & \multicolumn{3}{|c|}{ Frequency (people) } & \multirow{2}{*}{$\begin{array}{c}\text { Average } \\
\text { Score }\end{array}$} & \multirow{2}{*}{ Criteria } \\
\hline & & High & Moderate & Low & & \\
\hline 1 & Food Availability & - & 65 & - & 2 & Moderate \\
\hline 2 & Food Accessibility & 65 & - & - & 3 & High \\
\hline 3 & Food Absorption & 31 & 22 & 12 & 2 & Moderate \\
\hline & & Mean & & & 2 & High \\
\hline
\end{tabular}

Source: Primary Data Processing, 2017.

Table 3 presents that the highest score of those three food security aspects is food accessibility, score 3 and has high criteria; meanwhile, the other aspects, food availability and food absorption have scored 2 and have moderate criteria. Food accessibility is viewed from the access in fulfilling the needs for foods. Such access refers to social earnings, which are used to buy foods for about Rp 4,000,000 per month on average, accessible transportation to markets and foodstuff stores, good roads condition at the North, as well as some respondents have motorcycles and cars for their transportation. According to Rosyadi and Purnomo (2012), ability of the households to have access to foods is reflected on their expenses segment to buy foods. Correlation between expenses segment for foods and total expenses of the households are so-called working law. Such law states that the expense segment for foods has negative correlation with total expenses of the households. The higher expenses segment for foods, the lower food security of the household will be.

\section{CONCLUSION AND RECOMMENDATIONS}

Based on results of the research, it can be concluded that social empowerment and food security (farmer) at the North Sebatik Subdistrict have average score of 2 and moderate criteria. Social empowerment programs, which are intended to increase food security, should be implemented in accordance with the social needs and not only for building efforts, but also building both institutions and environments. Coordination between stakeholders/the interest 
parties should be built in implementing the agricultural development in order to increase food security at the borders.

\section{REFERENCES}

1. Aminah, Siti, 2015. Strategy in Increasing Empowerment of the Small Farmers toward Food Security (Strategi Peningkatan Pemberdayaan Petani Kecil menuju Ketahanan Pangan). Journal of Sociohumaniora. Volume 18. No 3rd November 2015, 253-261.

2. Babu, G. P., Kadian, K. S., Kumar, N. S., \& Sankhala, G. 2013. Empowerment of dairy farmers through ICT enabled I-kisan project in andhra pradesh. International Journal of Agriculture, Environment and Biotechnology, 6(4), 685-690.

3. Galié, A. 2013. Empowering Women Farmers: The case of Participatory Plant Breeding in Ten Syrian Households.Frontiers, 34(1), 58-92,136.

4. Hur, Man Hyung. 2006. Empowerment in Term of Theoretical Perspectives: Exploring a Typology of the Process and Components across Disciplines. Journal of Community Psychology. 34(5). 523-540.

5. Kasmel, A., \& Andersen, P. T. 2011. Measurement of community empowerment in three community programs in rapla (estonia).International Journal of Environmental Research and Public Health, 8(3), 799-817.

6. Kompasiana. 2013. National Alert against Utilization of Wastelands Will Create Food Security (Kewaspadaan Nasional terhadap Pemanfaatan Lahan Terlantar Dapat Mewujudkan Ketahanan Pangan).

7. Mardikanto, T. 2010. Concepts of Empowerment. UNS Press, Solo.

8. Laily, Sean Fitria Rohmawati. 2014. "Farmers' Empowerment in Increasing Food Security (A Study at Betet Village of Ngronggot Subdistrict, Nganjuk Regency) (Pemberdayaan Petani dalam Meningkatkan Ketahanan Pangan (Studi di Desa Betet Kecamatan Ngronggot Kabupaten Nganjuk)." Journal of Public Administration 2.1 (2014): 147-153.

9. Langerodi, M. C. 2013. Farmers' Empowerment in Dicators Modeling in Mazandaran Province, Iran. International Journal of Agriculture and Crop Sciences, 5(7), 769-776.

10. Mardikanto, Totok. 2010. Communication of Development. Reference for Academician, Practitioner, and Devotee of Developmental Communication. UNS Press. Solo.

11. Mun'im Akhmad 2012. Analysis on the Effects of Foods Accessibility and Absorption on Food Security at Regency that Has Food Surplus: Partial Last Square Path Modeling Approach (Analisis Pengaruh Faktor Ketersediaan Akses dan Penyerapan Pangan terhadap Ketahanan Pangan di Kabupaten Surplus Pangan: Pendekatan Partial Last Square Path Modelling). Directorate of Production Balance (Direktorat Neraca Produksi. BPS. Jakarta. Journal of Agroeconomy. 30(1) Mei $2012: 41: 58$.

12. Presidential Regulation No 22 in 2009. Policy on Acceleration of Local Resources-Based Consumption Diversities (Kebijakan Percepatan Penganekaragaman Konsumsi Berbasis Sumberdaya Lokal).

13. Rosyadi, Imron. "Food security of the households at the isolated villages (Tingkat ketahanan pangan rumah tangga di desa tertinggal)." Journal of Developmental Economy: A Review on Economic Problems and Development 13.2 (2012): 303-315.

Sugiyono. 2012. Methods of Quantitative, Qualitative Research and R\&D (Metode Penelitian Kuantitatif Kualitatif dan R\&D). CV Alfabeta. Bandung.

14. Laws No 18 in 2012. About Foods.

15. Widjajanti. Kesi. 2011. Social Empowerment Model (Model Pemberdayaan Masyarakat). Journal of Developmental Economy. 12 (2), 15-27.

16. Wrihatnolo RR, 2007. Empowerment Management: Introduction and Guidance for Social Empowerment (Manajemen Pemberdayaan: Sebuah Pengantar dan Panduan untuk Pemberdayaan Masyarakat). Jakarta: PT. Elex Media Komputindo. Gramedia Groups. 